\title{
Cultivating Critical Thinking through an English Reading Contest
}

\author{
Lan He \\ College English Department \\ Xiamen University Tan KahKee College \\ Fujian, China
}

\begin{abstract}
It is of great significance for a college English teacher to cultivate critical thinking on campus, and by theoretical study, reading is found to be an effective way to do it. In this paper, based on the research findings, a series of English reading activities were organized and made part of the students' extra-curriculum practice, which gradually prepared them for an English reading contest at the provincial or even the national level. The results have proved that our project was very productive in terms of raising the students' awareness of critical thinking and of ways to cultivate it.
\end{abstract}

Keyword-critical thinking; theoretical study; English reading; English reading contest; critical thinking awareness

\section{INTRODUCTION}

In the $21^{\text {st }}$ century, college English teaching in China is experiencing a crucial point where the role of the student is transforming from a passive recipient to an active participant. With the help of the Internet, the classroom is no longer a place for a teacher to impart knowledge to the student, but a place for the student to reproduce what they have already learned. Second language input in the classroom setting has to give way to second language output. This change seems to be beneficial to students because classroom teaching has become more student-oriented. Nevertheless, by closer observation, we can see that what a typical student has presented in class is very likely to be a collection of information based on the topic assigned by the teacher. It can be said that a college student's participations are at a rather shallow level. In other words, profound thinking is absent[1]. Under these circumstances, critical thinking becomes the goal for a large number of educators and teachers who are supposed to take the responsibility to cultivate it in the mind of students in order to make them highly creative to meet the needs of China's fast development in the current context.

To fulfill this responsibility, college English teachers in China need to be clear about what critical thinking is and what can be done on campus. To begin with, critical thinking originates from the conception of reflective thinking proposed by the American educator John Dewey [2]. Some scholars describe an ideal critical thinker as being curious, well-informed, and fully aware of the problem, cautious in making a judgment, ready to rethink, rational in forming an assessment and being dedicated to research. It follows that the core skills of critical thinking involve skills for interpretation, analysis, assessment, reasoning, explanation and self-adjustment. The other side of critical thinking includes dispositions of curiosity, alertness, hunger for rationality and reliability of the information.

Some educators in the research of cultivating critical thinking have arrived at the conclusion that the best path to it is through critical reading, which is defined as understanding the text in-depth, according to scholar Philip [3].

In recent years, educators in China have started to give concerns to critical reading and have already produced some results. However, their focuses are mainly on theoretical study and applying the results to in-class teaching.

Therefore, it may be a complementary attempt to shift a proportion of the focus on theoretical study of critical thinking to extra-curriculum practice, and this paper explores how an English reading project is accomplished with results proving to be productive.

\section{A Project to Cultivate CRITICAL THINKING THROUGH AN ENGLISH READING COMPETITION}

We take advantage of the reading contest for college students organized by Foreign Language Teaching and Research Press in China, known as the "FLTRP.ETIC CUP" contest, believing that the contest is an opportunity to motivate the students to get heavily involved. To promote this kind of reading, we launch a series of English reading activities on campus, developing their way of doing critical thinking in four dimensions, namely, to read and know, to read and reason, to read and question, and to read and write. We schedule our reading project this way to highlight the objectives in our cultivating process in hope that we can achieve our objectives step by step. This project starts each year from May and ends in December in accordance with "FLTRP-ETIC CUP".

\section{A. The first period to read and know}

In today's world, a person is not an isolated individual. Instead, each person is a particle in the network of the social environment which is becoming more and more complex. To know who a student is and how to react with the environment, he needs to know better about his roots, connections and potentials. By reading plenty of books, under the guidance of the teacher, he may be able to improve his cognitive ability and free his soul from the restrictions of his personal experience in real life. A broadened vision should be fostered.

For this period, reading is very much like the traditional reading, and the students are required to know more about 
literature and life philosophy. For example, we assign the students to read The Importance of Living by Lin Yutang and ask them to find the author's view on how to live a life. Their discovery is relatively new to them because they are always taught to work hard in their whole lifetime, but Lin Yutang[4], on the basis of the cycles of growth and decay, divides life into four periods, beginning with innocent childhood, followed by awkward adolescence; after that, life reaches a manhood of intense activities. The third period is middle age for gradual acquiring a more tolerant and a kindlier view of life. The last period is the old age, one of peace and contentment, which goes into eternal sleep eventually. In a broad sense, Lin Yutang compares the four periods to the cycle of the four seasons. As spring is characterized by growth, so is childhood. Similarly, the old age is like winter, with old organic things declining in quietness. The four periods are a beautiful arrangement, and any human individual, if in the old age working hard, is destroying the harmony of life arranged by Nature in advance.

When their hardworking attitude is in conflict with what proposed by Lin Yutang, the young students will have to stop and think for themselves. It is beneficial to know that youth is a time to work hard and people, at some age when they can't afford to work hard, should learn to compromise and happily take things as they are. In all, extensive reading helps college students to know better themselves and the world.

\section{B. The second period to read and reason}

The purpose of the reading project is not merely to accumulate phrases or information about life, but rather about what is under the sea of information and how things are related to one another. We need to help the students to reflect on what their senses provide and go beyond by doing deep thinking. As is pointed out by Plato[5], progress towards knowledge properly begins when we come to think of the world of our experience as irrelevant, and appreciate that it is abstract thinking that produces knowledge.

For this period, reading is deep thinking or reasoning, and our students are required to make comparisons, or to trace the thinking path of the author. For example, we assign the students to read The Importance of Living and Shakespeare: A Very Short Introduction and report their thinking about the similarity between Lin Yutang's poetic life periods and Shakespeare's.

It can be said that William Shakespeare sees a lifetime as a more profound concept with substantial implications. He expresses his view on life through his character Jaquesin As You Like It. A man in his lifetime is acting like this, "The world is a stage, / And all the man and women merely players. / They have their exits and entrances, / And one man in his time plays many parts, / His acts being many parts.(Act II Scene VII)"[6] Here human beings in this world pass through rites of passage. They are infants, school children, lovers, soldiers, businessmen, justices, and then they decline into senility, and die.

According to Shakespeare, a man who has come to the world is to play different parts or, in other words, to pass through rites of passage. The process complies with the law of growth and decay, by which Lin Yutang may be inspired. This idea of Shakespeare's can also be discovered in King Lear, who turns to be mud-headed at his old age.

The students are encouraged to judge whether Lin Yutang's view of life periods is a much-simplified version of Shakespeare's. Whatever their conclusion maybe, they will come to realize that Lin Yutang interprets Chinese culture with a strong touch of aesthetic value while Shakespeare dramatizes the real life to reveal the hidden truth. Hence, we appreciate Lin Yutang for his aesthetic style of writing and admire Shakespeare for his thinking so poignant that it helps us to interpret the complexity of the real life.

\section{The third period to read and question}

During this period, we ask the students to read classic books and to deepen their thinking by conversing with the great people in the books, and consequently to be able to question some mainstream ideas or to question some popular practices around us in today's world. As is put by Franklin, reading is easy, thinking is difficult, but the lack of one, then no use. But why are they supposed to read classic books? The reason lies in the fact that classic books contain systematic thoughts and everlasting wisdom. The students should learn to have an interaction with people in the books or the author while doing their reading. When there is difficulty in siding with the author, the students should be able to agree and disagree, or question to what extent the author is reasonable. Integrating the perspective of the author with their own, the young students may get out of their seemingly narrowmindedness and develop their plural cultural perspective to look at today's global community.

For example, we assign the students to read John Dewey and ask them to raise questions about the author's idea or about the phenomena around us. Interestingly enough, they disagree with the author very much. In the book, Dewey criticizes the traditional school by saying that it is all made for listening[7]. In his eyes, studying lessons out of a book is only another kind of listening, which means passivity and absorption. It marks the dependency of one mind upon another. To educate elementary students, the author suggests some places should be provided as their workshops or laboratories so that the children construct, create and actively inquire. While reading this book, the students of our project have much to say. Firstly, they don't think it practical. Given our country's real conditions, it is impossible to find so many qualified teachers to illuminate the children in "doing". It is ideal to provide the students workshops for them to create by following the teacher's instructions. Secondly, listening is an effective way to approach to truth. We can obtain knowledge by listening carefully and connecting the new with the network we have built in our brain. The school can be a place to learn from books and from the teachers.

On the other hand, the students agree with Dewey when he says that in a school, the child should be the center about which things like the appliances of education are organized. Still, there is a long way in China to have children at the center. This change is a revolution and cannot take place at present, but at college level, experiments in laboratories and workshops are becoming necessary and popular. 


\section{The fourth period to read and write}

With experiences of arguing for or against the author in the third period, the students come to the fourth period which provides them reading materials and ask them to write.

This is a period to help to assess and adjust their knowledge system. Although they have absorbed some new concepts or new perspective by doing plenty of reading in the previous periods, it still takes time for them to rebuild their knowledge system for themselves. By reading and writing, they should have opportunities to adjust their knowledge system a little and integrate the new things they have taken from reading into their original one. The challenge is to produce ideas forcefully with attention to good vision and sound logic. This period is a process of language output, which, according to Swain's output hypothesis, will make the students think in English. To be able to think in a foreign language is to obtain a new perspective to look at the world, which certainly is doing a different way of thinking and will contribute to critical thinking.

For example, the students are allowed to write an English essay about the poem Nature's First Green by Robert Frost. They should begin their essay with their comprehension of the poem, and then give their commentary ideas on the first green in real life in the second paragraph. It is an open-ended task. How inspiring the first green in nature depends on the vision of each student. Anyway, they should realize that nature's first green can be taken as a symbol of beautiful things around them. On the one hand, beauty can be eternal in each mind, although it brightens life merely for a short time and fades and vanishes from their sight. On the other hand, it makes no sense to seek a perpetual brilliant existence. To live a life is to grow and experience. As children of Nature, they should be conscious of the fact that life's process consists of growing and decaying, of rising and falling, which is one of the laws of Nature.

It can be said that to read and write helps to elevate the students' ability in thinking to some extent. During this final period of our project, top students are selected to take part in the provincial reading contest which is an overall test of the students' critical thinking.

\section{CONCLUSION}

To cultivate critical thinking through an English reading contest is a very productive project in the Internet context. When the lecture time on campus is being reduced and most learning takes place online, college English students hardly have time in class to be guided in extensive reading and in discussion about English books. Whether they are reading the paper backs or the e-books, they need to be organized and have peers to exchange their ideas so that they can't only be alert about cognitive differences and make proper judgments based on their understanding of the information conveyed in those books, but also adjust their knowledge system to develop plural perspectives to seek truth and happiness for human beings.

By taking part in an English reading contest, college students are more motivated to spend time in English reading and have a sense of achievement. This project is so innovative in its form that more and more students are attracted and they have done very well at the provincial level since it was started four years ago.
It is an amazing result that our selected students won twice the special prize in the "FLTRP·ETIC CUP" contest in Fujian province and got the license to take part in the final contest held in Beijing. In 2016, Huang Yi, a student of accounting major, finished the third in the semi-final held in Huaqiao University[8]. She impressed the panel of judges with her good reasoning ability and her life philosophy. More surprisingly, in 2018, XuYuhan, a student of e-commerce finished the first in the semi-final held in Fujian Normal University[9]. She made rational inferences and had her opinion about university education heard by all the judges.

The defect of our project is that it has not yet been organized online. With the fast development of the Internet, extra-curriculum activities should keep up with time and technology. Some more efforts are to be made in the future so that this project can be a ready option for all the students on campus.

In conclusion, our explorations in the field of practice have proved to be very productive in raising the students' awareness of critical thinking and of ways to cultivate it. Organizing extra-curriculum English reading activities can work flexibly together with in-class cultivation and provide data and support to further theoretical study.

\section{ACKNOWLEDGMENT}

This article is in the research project "Cultivating the students' critical thinking through an English reading contest” No. 20190501503.

\section{REFERENCES}

[1] Wen Qiufang, and Sun Min, "On key issues about critical thinking development in college EFL classroom," Foreign Language Learning Theory and Practice, 2015, vol. III, pp. 6-12. (In Chinese)

[2] John Dewey, How We Think, Lexington, Mass: D. C. Heath, 1910, p. 6.

[3] Zhang Sanxiang, and XieWeiwei, "The Basis and Strategy of Critical Thinking Reading,” Jiangxi Social Sciences, 2012, Vol.VII, pp. 261-263. (In Chinese)

[4] Lin Yutang, The Importance of Living, Shaan’xi Normal University press, Shaan'xi, 2008, p. 57

[5] Julia Annas, A Very Short Introduction to Plato, Foreign Language Teaching and Research Press, Beijing, 2007, p.82.

[6] William Shakespeare, As You Like It, The Commercial Press, Beijing, 2014, p.76.

[7] https://www.iyangcong.com/book/reading/2880

[8] http://flc.hqu.edu.cn/info/1081/4239.htm

[9] http://cfl.fjnu.edu.cn/d5/36/c6329a185654/page.htm 